\title{
Histórias futuristas mais antigas do que possam parecer: origem das idéias dos roteiros de ficção científica
}

\section{Futuristic stories older than might appear: origin of ideas of science fiction screenplays}

\author{
Carlos Alberto Machado ${ }^{1}$
}

\begin{abstract}
Resumo
O texto discute a origem das idéias da maioria dos roteiros de filmes de ficção científica modernos, bem como de conceitos literários como soft e hard, também presentes no cinema. Aponta-se a origem desses roteiros em sua maioria nas décadas de 1950, 1960 e 1970, períodos estes considerados férteis na literatura de ficção científica estrangeira. Também se aborda sobre as previsões casuais dos autores desse gênero que acabam trazendo suas idéias à contemporaneidade de forma despropositada, mas instigante, o que leva aos meios midiáticos a denominá-los de visionários. Alguns autores como Carrière, Xavier, Bez, Koff e Comparato auxiliam na corroboração dessas idéias. Assim, o leitor é levado a ponderar sobre a origem histórica dessas idéias.
\end{abstract}

Palavras-chaves: Roteiro. Cinema. Ficção científica.

\section{Summary}

The paper discusses the origin of the ideas of most movie scripts modern science fiction, and literaty concepts such as soft and hard, also present in the film. Pointed out the origin of these scripts mostly in the 1950s, 1960s and 1970s, they considered fertile periods in foreign science fiction literature. Also discusses about the casual predictions of the authors of this genre that end up bringing their ideas to contemporary unreasonably, but exciting, leading the media to call them visionary means. Some authors like Carrière, Xavier, Bez, Koff and Comparato assist in corroborating these ideas. Thus, the reader is led to reflect on the historical origin of these ideas.

Keywords: Script. Film. Science fiction.

\footnotetext{
${ }^{1}$ Doutor em Educação. Professor adjunto do departamento de Pedagogia da Universidade Estadual do Centro-Oeste (UNICENTRO). E-mail: cipexbr@yahoo.com.
} 


\section{Introdução}

O cinema é a única arte que é ciência e ao mesmo tempo, dela se utiliza para captar suas imagens e para exibi-las. (CARRIÈRE, 2006, p. 28)

Possivelmente seja como afirma Jean-Claude Carrière "os cineastas perceberam que a memória de imagens pode, às vezes, ser mais forte e duradoura do que a de palavras e frases." (2006, p.21). Dessa forma tendemos a lembrar mais nitidamente de imagens acumuladas na memória provenientes de filmes que assistimos em nossa vida, do que dos livros que lemos. É possível deduzir que o autor em questão separe a memória em compartimentos distintos que são usados de maneiras diferentes. "Estamos lidando com um outro gênero de memória, completamente diferente, que pode ser partilhada por povos diversos, não importa a língua que eles falem.” (CARRIÈRE, 2006, p.21)

Já a pesquisadora Rosália Duarte (2002, p. 38), afirma que diferente da escrita, cuja compreensão pressupõe domínio pleno de códigos e estruturas gramaticais convencionadas, a linguagem do cinema, está ao alcance de todos e não precisa ser ensinada. Sobretudo em sociedades audiovisuais, em que a habilidade para interpretar códigos e signos próprios dessa forma de narrar, é desenvolvida desde muito cedo. A maior parte de nós aprende a ver filmes pela experiência, ou seja, vendo na telona, ou na telinha e conversando sobre eles com outros telespectadores.

Ambos concordam que a maneira como as imagens são vistas e interpretadas pelos telespectadores tem uma importância particular e que longe de uma neutralidade, o olhar é penetrado por valores, normas e ideologias.

Nesse sentido pequenas mudanças podem ocorrer, mas são muitas vezes sutis, pois como afirma Carrière (2006) sobre o cinema: "uma linguagem que continua em mutação, semana a semana, dia a dia, como reflexo veloz dessas relações obscuras, multifacetadas, complexas e contraditórias, as relações que constituem o singular tecido conjuntivo das sociedades humanas" (p.22). Essa mutação influenciada pelo cotidiano de nossas vidas, também é observada nos enredos e narrativas de filmes com conteúdo científico, ou como é mais bem conhecido filmes de ficção científica (FC).

Apesar das considerações na área do jornalismo, - em cima das especulações dos escritores de FC, sobre acertos e erros na ciência ou na sociedade, estes, certamente nunca tiveram a intenção de fazêlo. Ao contrário, sempre tiveram intenção de criar enredos de puro entretenimento, produzindo arte, ou seja, uma forma de expressão que, como nos lembra Carrière, é contemporânea. A preocupação maior dos escritores e roteiristas tem relação com seu próprio tempo, trabalham para os que vivem no momento presente, no momento deles. Aqui e agora.

O escritor francês Julio Verne, por exemplo, considerado por muitos como o pai da FC, também era um pesquisador autodidata que sempre procurava estar por dentro de novas descobertas científicas e projetos especulativos de sua época. Suas idéias criativas costumavam ser embasadas em conhecimentos científicos de seu período histórico. Se os acertos ocorriam no futuro - nosso presente no caso, costumavam surpreender os mais incautos e ainda costumam tratá-lo na mídia como se ele fosse um tipo de guru ou adivinho. Obviamente era um visionário, mas não no sentido místico e sim literário, pois não tinha intenção de "prever o futuro". Verne costumava realizar pesquisa antes de escrever seus contos e por conta disso, sustentavase em novas descobertas científicas de sua época.

\section{Como lembra Flávio Aguiar (2003, p.} 140): "Vivemos também um momento em que possibilidades há pouco descritas como de ficção científica estão ao alcance da mão ou quase. Nossa capacidade fabulativa, herdeira do sonho, pode estar no limiar de uma potencialização que a nós ainda talvez pareça inusitada."

Como exemplo do que o autor afirma podemos descrever o trabalho de Gene Rodembbery que criou 
em 1963 a série Jornada nas Estrelas (Star Trek) onde previu de forma despropositada equipamentos sofisticados como: o tricorder utilizado na série para analisar aspectos geofísicos ou biológicos que vêm sendo aplicados atualmente em plantações, na agricultura e na medicina; o Hiposprey que hoje é estudado para aplicação na medicina; o comunicador de bolso constantemente utilizado pela tripulação da série Clássica da década de 1960, que espelha-se no atual celular; a agenda digital que o Capitão James Tiberius Kirk, protagonista da série costumava assinar ao final dos episódios, seria o atual MousePad, tecnologia já à disposição; a velocidade Warp que atualmente vem sendo estudada pela física teórica como a dobra do espaço tempo para encurtar distâncias. Ainda mostrou em quase todos os episódios da série a pistola de raios denominada phaser, que atualmente vem sendo estudada pelo laboratório americano NOVA, como um tipo de arma laser de mão sofisticada. Também não se podem ignorar os aspectos sociais demonstrados na série como espécies diferenciadas de alienígenas vivendo em harmonia, - que pode ser comparado com o convívio de diferentes etnias em nossa atual sociedade, trabalhando em conjunto. Até mesmo o polêmico tele-transporte que vêm sendo teorizado, já está teletransportando pequenas partículas de matéria. Ainda existe o Holodeck, apresentado ao público em séries mais atuais de Jornada nas Estrelas (Star Trek) e que nada mais é do que um tipo de jogo de entretenimento sofisticado que a ciência vem pesquisando atualmente e já aponta caminhos para alcançá-lo.

O já citado Julio Verne, outro autor visionário, também serve de exemplo. Em sua obra "Da Terra a Lua" de 1865, conta a história de três astronautas que entram no foguetão Columbaria, exatamente como em nossas primeiras missões Apollo. São disparados de Tampa na Flórida, que fica a cerca de 300 quilômetros de Cabo Canaveral onde os atuais lançamentos são realizados e que na Lua planejavam alunissar no Mar da Tranqüilidade, mesmo local da primeira descida de Neil Amstrong.
Também realizam órbita elíptica em formato de oito, a mesma técnica de vôo utilizada pela NASA quando enviou os primeiros homens a órbita da Lua quase cem anos depois, em 1969. Noutra obra do mesmo autor "20 mil Léguas Submarinas" de 1870 o Capitão Nemo e o submarino nuclear Nautilus, como os atuais submarinos nucleares, escafandros e as fazendas submarinas - criações de maricultura, ostras, algas e mariscos, atualmente uma realidade mundial, etc.

As informações científicas nesses casos são desprovidas de tecnologia avançada? De forma alguma. Ao contrário, possuem muita tecnologia e até mesmo criativas invenções e sofisticados aparelhos tecnológicos que espantam até mesmo os mais habituados a vivenciá-los. Tudo imaginado pela mente fértil desses escritores.

É o caso, por exemplo, de "2001 - uma odisséia no espaço", escrito por Arthur C. Clarke, e produzido por Stanley Kubrick em 1968, onde o homem pisa na Lua um ano antes de realmente ocorrer em nossa realidade. Fato que por conta dessa similaridade, até hoje, existem pessoas que ainda duvidam da veracidade do primeiro homem a Lua. No conto e no filme de 2001, o autor vai ainda mais longe: ao planeta Júpiter e a um de seus satélites naturais Europa, para onde a NASA está pretendendo lançar nos próximos anos uma sonda espacial que buscará indícios de vida, utilizando uma bateria nuclear para derreter a calota de gelo e uma câmera submarina para enviar imagens exclusivas de prováveis vidas alienígenas, nesse caso especulamos, marinhas talvez. Deverá ser um evento histórico sem precedentes, principalmente se obtiverem êxito. Tanto no filme, quanto no livro Clark, previu que seriam encontradas algas verdes naquele satélite do gigantesco gasoso Júpiter. Não seria de espantar se a sonda em questão encontrasse em Europa, um dèjá vu clarkiano. Seria mais uma vez, a realidade imitando a ficção. 


\section{Roteiros - Poços de Ideias}

Certa vez em uma locadora de vídeos caseiros, um cliente solicitou a uma funcionária do estabelecimento um filme de aventura e FC para assistir em sua residência. Ela voltou com duas sugestões para o cliente que inicialmente observou o ano de produção do filme na parte de trás dos estojos. Um deles, era daquele mesmo ano e o outro, já tinha uns cinco anos de produção. $\mathrm{O}$ cliente recusou o segundo, afirmando categoricamente que o referido filme estava "velho". Velho? Com apenas cinco anos de produção? O que diria aquele cliente se soubesse que a maioria dos filmes de FC, mesmo retratando cenários futuristas e modernos são baseados em livros de origem antiga, ou "velhíssima" como diria o tal cliente?

Ao contrário do que possa parecer à maioria da população e apesar dos filmes de FC hollyhoodianos em sua maioria demonstrarem recursos sofisticados, onde se imaginam futuros possíveis, ou até mesmo utópicos, muitos roteiros foram idealizados baseados em livros originalmente escritos e pensados nas décadas de 1950, 1960, ou 1970 e não por autores contemporâneos. Isso não significa que escritores atuais não sejam capazes de fazê-los, mas apenas que ainda não foram descobertos pelos produtores interessados, ou devidamente valorizados pelas empresas cinematográficas. Percebem-se também boicotes por parte do sindicato dos roteiristas americanos como o de Los Angeles. O escritor e roteirista J. Michael Straczynski é um bom exemplo do que explanamos aqui. Foi o criador da série de FC "Babylon 5", exibida no Brasil na década de 1990 pelo canal a cabo Warnner, que não foi devidamente valorizado por seus conterrâneos, mas sim por seus muitos fãs estrangeiros, incluindo o Brasil. O mesmo pode-se afirmar sobre a série televisiva de Jornada nas Estrelas, série clássica, que em seu próprio período original de exibição não foi muito apreciada. Durou apenas três anos quando a intenção inicial era que durasse pelo menos cinco. Seus milhões de fãs surgiram apenas após a exibição de suas reprises posteriores realizadas em outros países.
A ciência mostrada nos recentes filmes de FC muitas vezes é comparada pela mídia à ciência de balcão dos laboratórios dos atuais cientistas. Isso se denota por conta da preocupação e pesquisa realizada por especialistas em ciência que são contratados como consultores pelos roteiristas e/ou escritores de scripts. O autor que criou a primeira versão, nem sempre voltada para o cinema, mas sempre com o intuito de ser publicado em formato de livro, pode ter experenciado conhecimentos suficientes que costumam surpreender com suas "adivinhações" científicas. Ao ser adaptado para o cinema, ou para a televisão, essas informações científicas acabam muitas vezes despropositadamente ou equivocadamente, sendo deturpadas fugindo a realidade dos laboratórios. Possivelmente, isso é provocado pela busca final da preferência popular sobre filmes do gênero, constantemente prevalecendo sobre o que realmente poderia acontecer. Assim sendo, informações distorcidas são transferidas, como costuma acontecer com informações mediáticas equivocadas, correndo riscos de formar um tipo de desinformação científica.

$\mathrm{Na}$ classificação da $\mathrm{FC}$, apesar de nem todos concordarem, existem considerações que definem se a história é hard, com explicações científicas mais aprofundadas ou soft, com conotações sociológicas despreocupadas com o rigor científico. De qualquer forma ambas podem fazer parte da ciência, pois enquanto a primeira é influenciada majoritariamente pela área de exatas, a segunda abrange mais especificamente a área de humanas. Apesar dessas afirmações conceituais, nem sempre essas observações procedem. Observa-se na prática que um escritor pode escrever um conto de maneira hard, utilizando teorias biológicas, ou da área de humanas tão propriamente, quanto um físico ou engenheiro em sua área. Por esse motivo os termos hard e soft, são empregados tanto para histórias com ênfase de cunho científico, quanto de cunho sociológico.

Nem sempre os roteiros são adaptações de livros. Em muitas ocasiões os produtores, que são os 
principais responsáveis financeiros pelas produções cinematográficas, procuram diretamente roteiristas que não se utilizam de livros, mas de suas próprias ideias.

Quase sempre existem grandes livros por trás de grande filme. Não me refiro a exatamente à tarefa reconstrutiva de adaptação de romances da literatura universal para as telas, mas principalmente às idéias que surgem para desvelar a rede de significados presentes em obras cinematográficas clássicas ou contemporâneas. (KOFF, 2002, p. 21)

No inicio das décadas de 1940 e 1950 as produções cinematográficas procuravam utilizar escritores de $\mathrm{FC}$, até perceberem que o público da época, não estava muito preocupado com detalhes técnicos que se aproximavam mais do estilo hard e sim com puro entretenimento mais ao estilo soft. Apesar de toda regra possuir uma exceção, notase que a qualidade das histórias está intimamente relacionada com a qualidade dos roteiros baseados, ou adaptados, em livros já bem conhecidos. Os roteiros livres, ou criados pelas ideias dos roteiristas são criações de cunho comercial e apelam para o consumismo imediato. A preocupação principal não é com a história em si, mas sim com o lucro da bilheteria. Sem ofender a inteligência do espectador, é possível perceber que um filme com roteiro de qualidade, ou considerado muito bom, não necessita de grandes efeitos especiais, ou gastos exacerbados. Por exemplo, países latino-americanos como o Brasil ou a Argentina, já estão plenamente equipados e adequados para realizar filmes de FC, sem preocupações com gastos holyhoodianos. O Brasil já realizou algumas produções desse tipo, que passaram despercebidas a olhos mais atentos. Como exemplo pode-se citar "Abrigo Nuclear" de Roberto Pires de 1981; "Brasil Ano 2000” de Walter Lima Jr. de 1969; "Parada 88: O Limite de Alerta" de José de Anchieta de 1978; "Quem é Beta?" de Nelson Pereira dos Santos de 1973, "O Quinto Poder" de Alberto Pieralisi de 1962, entre muitos outros que em alguns casos seguem moldes do cinema europeu. Pode-se evidenciar ainda esse gênero junto com a comédia da produtora brasileira Atlântida na qual Oscarito estreou como protagonista ao lado de Grande Otello. Ambos participaram do filme "O homem do Sputnik" de 1959, comédia familiar de grande sucesso na época, re-exibida pela TV Cultura em 2004 e disponível atualmente em DVD.

Retornando ao roteiro de filmes de FC atuais, percebe-se que as produtoras cinematográficas americanas e canadenses, principalmente as de televisão, resgataram o interesse por filmes de cunho mais realista, ou hard através da consultoria de cientistas como é possível evidenciar em "2001: Uma Odisséia no Espaço" de 1968, ou em séries televisivas como Jornada nas Estrelas (Nova Geração, Deep Space Nine, Voyager e Enterprise) respectivamente da década de 1990, "Arquivo X” (1993), Stargate (1997) e a nova versão de Galáctica (2004), considerada pelos fãs de FC como a melhor série de FC produzida neste novo século. A série original de 1978, era mais soft e não fez tanto sucesso como segunda versão.

No ano de 1895 quando H. G. Wells escreveu o romance "A Máquina do Tempo" e em 1960 foi realizada a primeira versão cinematográfica do romance dirigida por George Paul. Quarenta e dois anos depois, ou seja, em 2002 é realizado um remake mais próximo do original, dirigido pelo bisneto do criador da obra, Simon Wells.

“A Última Esperança sobre a Terra" foi publicado em 1954 escrito por Richard Matheson. Adaptado para os cinemas primeiramente em 1964 como "Mortos que Matam" com direção ítalo-americana de Ubaldo Ragona e Sidney Salkow, como "A Última Esperança da Terra" (The Omega Man), em 1971, dirigido por Boris Sagal e como "Eu sou a lenda” em 2007 pela direção de Francis Lawrence.

Outro exemplo é o filme distópico "Blade Runner: o caçador de andróides" realizado em 1982 pelo diretor Ridley Scott, escrito por Philip Kindred Dick em 1968, com o título original de "Do Androids Dream of Electric Sheep", tradução literal "Faça o sonho dos carneiros andróides elétricos", que retrata o ano fictício de 2029. Philip K. Dick também é 
autor da obra "O Impostor" escrito originalmente em 1953, exibido nas telas dos cinemas em 2002 e que imagina o ano de 2079. Ambas as histórias mostram o quão difícil é confiar em si mesmo. A teoria bakhtiniana pode ser avaliada nessas duas obras da auteridade, analisando as várias identidades e personalidades dos protagonistas.

Outro filme que arrecadou milhões de dólares e bastante conhecido por uma grande parcela da população mundial foi "Alien, o $8^{\circ}$. passageiro" de 1979, dirigido por Ridley Scott. Poucos sabem, mas Alien foi originalmente produzido em 1957, inspirado em um filme de produção italiana, considerado pelos cinéfilos como um filme de categoria "B", ou seja, de baixa produção. Já "O Vingador do Futuro" (Total Recall), se passa em 2084, produzido em 1990, dirigido por Paul Verhoeven, e refeito em 2012 com o mesmo título na direção de Len Wiseman. Ambas as versões foram inspiradas na história original de Philip K. Dick escrita em 1966 com o título We Can Remember It For You Wholesale.

O clássico romance "Frankenstein" de Mary Shelley foi escrito e publicado em 1817 e já ganhou várias versões cinematográficas no século passado. Este poderia ser considerado uma exceção à regra, visto que a maioria da população acaba conhecendo-o por meios midiáticos diversos.

O texto literário também é fruto da ciência, da mente de seu criador, e acompanha a humanidade através da escrita, desde seus primórdios, seja através de sinais ou símbolos, seja através de textos históricos. O texto evoluiu e com ele, também seus leitores que com o passar do tempo, ficaram mais exigentes. À medida que os filmes foram tomando corpo e copiando os livros de forma narrativa fílmica, os leitores menos atentos podem não ter percebido, mas, foi se formando uma nova arte diferenciada em sua origem narrativa. Tornouse individual e independente, portanto, não mais dependente de seu progenitor.
Dessa forma podemos compreender que nem sempre a narração do livro condiz com a narrativa do filme que é outro ponto de vista e por esse mesmo motivo, muitos autores e cinéfilos puristas se decepcionam. Esquecem de analisar essas diferentes formas de ver.

\begin{abstract}
Afinal, livro e filme estão distanciados no tempo; escritor e cineasta não tem exatamente a mesma sensibilidade e perspectiva, sendo, portanto de esperar que a adaptação dialogue, não só com o texto de origem, , mas com o seu próprio contexto, inclusive atualizando a pauta do livro, mesmo quando o objetivo é a identificação com os valores nele expressos. (XAVIER, 2003, p. 62).
\end{abstract}

Mesmo inconscientemente existe uma inevitável comparação do filme com a história original. Essa modificação nem sempre intencional do texto original através de adaptações para roteiros muitas vezes não é condizente entre eles, pois a comunicação é uma expressão que tem uma intencionalidade e um destinatário, portanto, se mudamos a comunicação - através de ruídos - temos uma mensagem diferenciada da original, ou seja, daquela que o escritor queria passar a princípio.

De qualquer forma, como já mencionado anteriormente, o cinema bem como a literatura não têm a responsabilidade de mostrar a realidade, mas sim sua representação, e dessa maneira, assume seu papel neutro em transmitir informações originais, pois passa também a ser um criador de novas informações. Sendo assim, ao cinema, interessa mais a leitura da narrativa cinematográfica. Algumas vezes essa narrativa pode estar em comum acordo com o texto original, mas também esta sujeita a modificações da equipe de produção do filme. A equipe de produção, nesse caso, acaba se tornando "o ruído" que altera a representação. Entende-se por ruído, tudo aquilo que transpassa a produção do filme. A intencionalidade e o destinatário podem dessa forma mudar substancialmente, pois a imagem aqui retratada vem carregada de subjetivas experiências. Mesmo que o cineasta queira ser fiel ao texto original, sua interpretação da realidade, seu ponto 
de vista é modificado e influenciado por ideologias. Existe um a priori doutrinário que domina a todo custo. Dessa forma somamos ideologias do escritor, do roteirista e do diretor, que ao final ainda podem entrar em choque com as ideologias dos próprios espectadores que interpretam o filme a sua maneira.

El punto de vista, em su sentido más amplio y hondo, implica conceptos e ideas de toda clase (filosóficas, sociales, artísticas) y conlleva fenómenos sensoriales que, de modo específico, en las obras de artes visuales suponem una posición de observación sensorial, de percepcíon visual, un punto de vista muy concreto, en su sentido visual, geográfico, espacial. (BEZ, 2006, p. 32)

Um detalhe técnico de produção como uma câmera posicionada de uma determinada maneira ou ângulo pode, por sua vez, demonstrar outros pontos de vista não necessariamente relacionados à imaginação do escritor, ou mesmo de seus leitores. Dependendo do ponto em que a câmara é posicionada no set de filmagem, pode evidenciar " $n$ " situações, para uma mesma tomada de cena. Neste ponto, evidencia-se certo grau de importância a afinidade do diretor com a equipe de produção e com o roteiro original. "Nossa imaginação individual deriva de outra imaginação, mais vasta e mais antiga do que nós mesmos. Somos apenas um grão no oceano" (CARRIÈRE, 2000, p. 37).

A realidade vivenciada pelo escritor em sua época, em seu período de tempo, somado à suas expectativas de futuro, ou seja, realidades imaginadas pelos escritores de FC, eram em muitos casos otimistas utópicos, idealizando um por vir sem muitos problemas, pois a tecnologia por sua vez estaria aí para contorná-los. Ocorre que esses preceitos sociais continuam idênticos e o mesmo ocorre com as esperanças de um futuro melhor, pois a humanidade pouco evoluiu, ou, modificou-se no último milênio. Por exemplo, o futuro aguardado para o ano 2000, nas décadas de 1950, 1960, 1970 e 1980 não é necessariamente o que ocorre hoje em dia (2013). Automóveis voadores como vistos em “Minority Report: a nova lei" de 2002 com Steven
Spielberg na direção, também escrito por Philip k. Dick em 1958, robôs domiciliares evidenciados em "O Homem Bicentenário" de 1999 dirigido por Chris Columbus e escrito por Isaac Asimov em 1976, e "Eu Robô" também escrito por Isaac Asimov em 1950 e filmado em 2004, classes sociais unificadas como vistas no clássico "Metrópolis" do cineasta alemão Fritz Lang, filmado em 1927 e que retrata o ano de 2026, ou em "Admirável Mundo Novo" (Brave New Word) de Aldous Huxley, escrito em 1932, filmado em 1980 e re-filmado em 1998, que em conjunto com o já citado "Inimigo Meu" (Enemy Mine) de 1985, mostram a ausência ou inclusão de discriminações raciais experenciadas ainda estão longe de se tornarem realidades.

Claro que muitas modificações ocorreram, mas em períodos diferentes dos previstos, até mesmo antes do ano 2000, e geralmente por exigências de mercado. O capitalismo, em sua ânsia de sobrevivência procura controlar os meios de produção e de consumo muitas vezes freando criações brilhantes, por não se encaixarem com seus ideais de sociedade.

Dessa forma, podemos especular que as visões dos escritores de FC em suas previsões despropositadas, poderiam ser retratadas da seguinte maneira: apanham vários recortes de inúmeras épocas e os juntam em um único corpo. Esses recortes transforma-se em uma colagem similar a um mosaico. Assim, eles conseguem imaginar muitos aspectos da sociedade, mas são previsões não necessariamente de um futuro que ira ocorrer.

Las obras artísticas están configuradas por imágenes (símbolos, signos estructurados, sistematizados, em general), que fucionan lo real y lo fantástico, lo experimentado objetivamente y lo imaginado, lo objetivo y lo subjetivo, lo racional y lo emocional. Coherentemente, unifican el sentimiento, el conocimiento. El descubrimiento, la explicación y demás procesos similares, con la imaginación y la creación de algo nuevo, de una obra que se añade y lo enriquece. (BEZ, 2006, p. 65) 
No clássico filme distópico inglês "1984" de Michael Radford, escrito por George Orwell em 1948, possivelmente inspirado nas conseqüentes tragédias da segunda guerra mundial, o autor descreve uma sociedade autoritária, desprovida de democracia e policiada pelo Grande Irmão, ou Big Brother. No ano de 1984, a imprensa mundial aproveitou a ocasião tentando comparar o filme com a realidade afirmando que suas previsões não surtiram efeito. Hoje porém, percebe-se que Orwell estava correto em afirmar a vigilância impune do filósofo Michel Foucault. Basta ligar a televisão em qualquer parte do mundo para assistirmos um programa de mesmo nome, repleto de câmeras em todo canto, não escondendo nem a intimidade e privacidade de seus participantes que se expõem, induzidos pelos caprichos do capitalismo consumista. "1984" em 2013, também se espelha nas residências particulares, nos escritórios, nos elevadores, nas máquinas automáticas de bancos, nas lojas, nos Shoppings Centers, nos coletivos e até mesmo nas ruas! Somos constantemente vigiados, despidos de nossa liberdade, embora muitas vezes desatentos dessa vigia, e quando não, com a genuína justificativa de que é para nossa própria segurança. Isto nos remete ao "panóptico"2 de Foucault prevista antecipadamente no conto de Orwell. Além do fato de que nossa sociedade atualmente anda tão desprovida de autenticidade que não precisa mais ser vigiada diretamente para ser manipulada. Ainda é possível apontar para a manipulação sutil, psicológica, subliminar até, que nos transporta sem nos apercebermos, usando nossas necessidades básicas para um tipo de atração irresistível do consumo. A sociedade consumidora está cada vez mais sendo preparada para trocar constantemente, seus automóveis, eletrodomésticos, eletroeletrônicos, vestimentas, mesmo sem necessidade de fazê-lo.

Da mesma maneira que a pessoa - leia-se leitor, acaba assistindo a um filme, é fato também que muitos que o assistem acabam por se interessar também na leitura da obra original, o que pode ser visto, do ponto de vista didático pedagógico como um fator preponderantemente sensato. É pertinente destacar também que a imaginação dos leitores no ato da leitura acaba sendo nesse caso, muito mais rica e inegavelmente mais criativa do que o já formatado filme de película. Talvez, o que falte, seja justamente a consciência dessa realidade por parte dos leitores e de alguns críticos que insistem em comparar as obras.

O filme "Solaris" de 1972 dirigido pelo russo Andrei Tarkovski e escrito pelo polonês Stanislaw Lem em 1961, apesar de lento, é um exemplo que serve para retratar o que citamos aqui. Uma obra poética que demonstra talento na sétima arte, considerada também uma obra prima em sua forma gutembergeriana. Assistir ao filme em sua visão russa é tão agradável quanto imaginar a cena na leitura do livro polonês. Nesse caso, ambas as formas apesar de diferentes, são apreciáveis. O diretor demonstrou afinidade e similaridade genuínas no que tange a obra original, mas essa regra não vale para todos os exemplos citados aqui. Já não se pode dizer o mesmo da nova versão estadunidense com o mesmo nome refeita em 2002, nas mãos de Steven Soderbergh.

Para alguns autores tradicionais, a criação literária não se compadece com os registros cinematográficos, mesmo a realidade servindo de padrão para os roteiros, pois a criação processa-se numa folha de papel e não em uma tela e se realiza por

\footnotetext{
${ }^{2}$ Foucault observa na obra "Vigiar e Punir" que é mais eficiente vigiar do que punir na "sociedade disciplinar". Assim, nessa sociedade para que as normas fossem interiorizadas pelos indivíduos, foram desenvolvidos mecanismos de vigilância, que podem ser comparados à estrutura arquitetural de Jeremy Bentham (panóptico), planejada para observação constante em prisões, fábricas, escolas e manicômios. (FOUCAULT, 1987).
} 
um ato individual de um escritor e não de um grupo ou equipe de produção cinematográfica. De qualquer forma para outros, o cinema também é considerado arte, arte mecânica que vem se aprimorando com o passar do tempo e como tal, também se cria e é valorizada. Modifica-se e se transforma passando a ser outra obra. Por esse mesmo motivo no cinema, um livro jamais será copiado e sim, modificado, para pior ou, para melhor. Dessa forma o cinema vem recebendo por intermédio da FC, novos elementos mágicos e novos delírios de imaginação que se limitados apenas pelo processo da censura, reforçam sua conotação de sétima arte.

É possível perceber que a expectativa do público em relação a filmes de FC sempre é em busca de tecnologias modernas além das já conhecidas, ou seja, querem ver na ficção, a prova das especulações teóricas, em muitos casos apenas hipóteses ou ainda elucubrações científicas. Querem evidenciar na telona como seria sua aplicação prática. Essas especulações teóricas por sua vez se modificam e nem sempre são possíveis de realização, ou por impossibilidades científicas, ou mesmo por desinteresse ideológico, político, ou econômico. $\mathrm{O}$ que seriam das fábricas de pneus quando e se realmente inventassem veículos de transporte voadores acessíveis à população? E das farmácias, quando descobrirem a cura para a maioria das epidemias como a da gripe? Quantos motores movidos a água ou lixo já foram inventados? E o que dizer da lâmpada que dura para sempre criada recentemente pela indústria OEP Eletric pela quantia de 35 euros? Além de ser econômica, não gera resíduo e produz menos $\mathrm{CO} 2$. Este tipo de produto durável contraria a absolescência programada, quando empresas fabricam propositadamente produtos não duráveis para serem constantemente consumidos. Sem contar que estamos em crescente e desproporcional crescimento demográfico. Para onde irá a humanidade se ela continuar a aumentar e ocupar tanto espaço? Ou se criam dispositivos de controle populacional eficientes e preferencialmente não como na China, ou teremos que enfrentar sérios problemas sociais brevemente. Enquanto as soluções não surgem os filmes de FC estão aí para tentar responder de maneira especulativa e cheia de imaginação possíveis soluções e alternativas.

A busca da consciência ecológica e de uma humanidade auto-sustentável também é evidenciada em filmes distópicos como: "O Segredo das Águas" (Waterworld) dirigido por Kevin Reynolds e protagonizado por Kevin Costner, escrito em 1986 e filmado em 1995, onde assistimos uma conseqüência possível em relação ao degelo da Calota Polar, segundo alguns cientistas, seqüela inevitável do buraco da camada de ozônio.

O mesmo assunto e pelo mesmo motivo é explorado no recente e catastrófico filme "O Dia depois de Amanhã" de 2004, dirigido e escrito por Roland Emmerich, de forma mais assustadora e realista possível. Já em "O Mensageiro" (The Postman) de 1997, também com Kevin Costner como produtor e protagonista, é explorada a idéia pós-apocalíptica depois da Terceira Guerra Mundial, onde existia uma evidente falta de comunicação entre os sobreviventes. Devido a essa deficiência destacase o resgate no passado da idéia do funcionário dos correios, o carteiro, que na película fílmica utiliza o cavalo como veículo principal na via de acesso para o resgate das comunicações. Assistindo ao filme é inevitável não recordar o depoimento de Albert Einstein quando indagado por um jornalista sobre sua opinião com relação Terceira Guerra Mundial, afirmou que não sabia como seria essa guerra, mas, a quarta, com certeza seria com paus e pedras...

Os Buracos Negros definidos como objetos inobserváveis como bem o demonstra Teixeira Coelho Neto (2001, p. 208), são os preferidos da ciência do cinema, pois eles podem ser demonstrados nas telas do cinema a revelia, misturados aos objetos observáveis criando dessa forma um universo nem sempre verossímil, mas aceitável pela imaginação humana. Como também afirma o mesmo autor, Einstein, não estava nem um pouco preocupado com as demonstrações práticas de suas teorias. 
Satisfaz os críticos e os mais exigentes e satisfaz a consciência ecológica que mais dia, menos dia, aflora em todos nós. A questão de sobrevivência da humanidade sempre foi uma prioridade que pode ser observada tanto na literatura quanto no cinema desse gênero desde a década de 1940, nos escritores de FC daquela época, prevalecendo em suas obras dessa forma, até nossos dias.

Algumas vezes, uma história antiga de FC é homenageada como no filme de Wolfgang Petersen "Inimigo Meu" (Enemy Mine) de 1985, com Dennis Quaid, que possibilita a discussão sobre o preconceito e a discriminação. É possível que esse roteiro entre outros que serão citados mais adiante, foi como lembra o roteirista Doc Comparato (2000), baseado, inspirado, ou recriado no conto "A Arena", escrito por Frederic Brown em 1958, publicado no Brasil pela editora Cultrix, em uma coleção denominada "Maravilhas da FC" de 1959. O conto original evidencia diferenças e obriga duas espécies alienígenas que disputam entre si, a definirem-se em sua existência, através de uma disputa imposta por uma terceira espécie considerada superior. Também é possível verificar outras homenagens a essa mesma história, na série "Galáctica Astronave de Combate" (Battlestar Galactica) de 1978. No episódio "O Retorno de Starbuck" (The Lost Warrior) de Herman Groves e Donald P. Bellisario, onde Starbuck, um dos protagonistas e um dos andróides Cilônios, conhecido por "Olhos Vermelhos", inimigos naturais, ficam isolados náufragos em um planeta desabitado, necessitandose mutuamente para sobreviver e auxiliar uma mulher e seu filho. Outro possível exemplo é o episódio "Arena", história baseada no original de Frederic Brown de 1958, que levou o mesmo nome, na série "clássica de Jornada nas Estrelas" de 1967, onde, em meio a uma guerra, dois representantes de duas espécies diferentes, o capitão James Tiberius Kirk da Terra e um capitão do povo alienígena Gorn, são escolhidos por uma terceira espécie considerada superior os Metrons. Os dois são enviados a um lugar neutro, onde o objetivo é duelar até a morte.
Ambos seriam avaliados pelos Metrons e aquele que sobrevivesse voltaria a sua civilização, que não seria mais exterminada. Novamente em "Jornada nas Estrelas", agora na série "Nova Geração" de 1991, com direção de Winrich Kolbe, evidenciamos o episódio "Darmok" onde o Capitão Picard encontra uma nova espécie alienígena, os Tamarians, que se comunicam apenas por metáforas baseadas em sua própria história. $\mathrm{O}$ tradutor universal nesse caso de nada serviria. O capitão Picard e o capitão da nave alienígena são transportados isoladamente para um planeta inóspito, onde com a convivência para sobreviverem conseguem se comunicar pelas metáforas. Outro seriado que homenageia a mesma história de Frederic Brown é a série inglesa "UFO" de 1970, idealizada e produzida por Gerry e Silvia Anderson. Em um dos primeiros episódios um dos protagonistas, o Coronel Paul Foster acidenta-se em nosso satélite natural a Lua, concomitantemente com uma nave alienígena invasora. Preso com seu adversário, ambos percebem que para sobreviver precisam deixar suas diferenças de lado e juntar forças. Outra série que homenageia a mesma história é "Quinta Dimensão" (The Outer Limits). Em sua primeira temporada, produziu em 1963 o episódio número 27, denominado "Diversões e Jogos" (Fun and Games). Nele, um casal é arremessado em uma arena de um planeta inóspito onde devem lutar para sobreviver. Eles são a atração principal de vários povos alienígenas que assistem as lutas, como o antigo povo romano costumava fazer no coliseu.

Outro filme de FC para o cinema baseado na literatura especializada que serve de exemplo para o que vimos expondo até aqui é "Duna", de David Linch refilmado em forma de mini-séries "Duna" de 2002 e "Filhos de Duna" de 2004, de Greg Yaitanes, consideradas óperas espaciais ou novelas espaciais, estas mais fiéis ao livro do que a obra de Linch, ainda sofrendo críticas comparativas dos fãs mais exigentes, leitores da saga original de Frank Herbert que a escreveu em 1965.

"Planeta dos Macacos" (Planet of the Apes) escrito por Pierre Boulle em 1963, também foi 
transportado para o cinema. Filmado inicialmente em 1968 e dirigido por Franklin J. Schaffner foi refilmado com o mesmo título em 2001, sob a batuta de Tim Burton e posteriormente em "O Planeta dos Macacos, a origem" (Rise of the Planet of the Apes) de 2011, na direção de Rupert Wyatt, que conta a origem da série de filmes.

"A Aldeia dos Malditos" (Village of the Damned) de Wolf Rilla, título original do livro "The Midwich Cuckoos" publicado em 1957, novela de John Wyndham de 1963, foi filmado na Inglaterra em 1960. Re-filmado em solo americano em 1995 com o título ligeiramente modificado "A Cidade dos Amaldiçoados”, pelo americano Jonh Carpenter com Christopher Reeve e Kirstie Alley encabeçando o elenco. Os ingleses chegaram a realizar uma sequência denominada "A Estirpe dos Malditos" (Children of the Damned) em 1963, que não foi re-filmada. Ambos os filmes, realizados originalmente em preto e branco, recordam as antigas séries de televisão da década de 50: “Além da Imaginação" (Twilight Zone) de 1959 a 1964 com cinco temporadas, criada por Rod Serling e dirigida por Stuart Rosemberg com cinco temporadas e "Quinta Dimensão" (The Outer Limits) de 1963 a 1965, co-produção EUA/Canadá com três temporadas exibida pela rede $\mathrm{ABC}$ de televisão. Estas duas séries serviram de laboratório e lançaram no mercado cinematográfico estadunidense vários atores até então desconhecidos. Também obtiveram seqüências em outras décadas pela mesma produtora a CBS em 1980 “O Novo Além da Imaginação”, com três temporadas que perduraram de 2002 a 2004; "Além da Imaginação" pela UPN com apenas uma temporada e "Outer Limits" de 1995 a 2002 com sete temporadas. Mesmo nas atuais continuações, percebe-se a repetição de alguns dos roteiros dos antigos escritores.

Outro filme de FC que ilustra nossa teoria é o recente "John Carter entre dois mundos", lançado nos cinemas mundiais pela Disney em 2012, tendo na direção Andrew Stanton, que fez bastante sucesso nas bilheterias. A obra original intitulada
"Uma princesa de Marte", foi publicada por Edgar Rice Burroughs em 1917, que criou a personagem John Carter em 1912.

Então, como quer que imaginemos o futuro, quaisquer que sejam as formas e cores que lhe atribuamos, as imagens que criamos envelhecem. E assim como não conseguimos reconhecer, nas silenciosas previsões em preto e branco dos anos 20 , o período em que vivemos, da mesma forma todas as nossas imagens de hoje serão amanhã imagens de ontem. (CARRIÈRE, 2006, p. 134)

\section{Conclusão}

Interessante lembrar como bem observa Rogério Ferrer Koff (2002), que antes de 1968 - ano do filme "2001: uma Odisséia no Espaço", os roteiros de FC adaptados para o cinema, preocupavamse apenas com o puro entretenimento e portanto eram considerados filmes do tipo "B". A partir do filme originalmente escrito por Clarke o cinema de FC começou um novo processo, mais reflexivo e intelectual. Nesse sentido, possivelmente essa obrigação cinematográfica fez com que roteiristas e produtores percebessem a importância da literatura de FC mormente nos períodos citados até aqui, muitos deles premiados inclusive. Isso também evidencia que distante dos filmes de FC "B", a literatura do mesmo gênero estava muitos passos a frente.

Sobre a literatura o estudioso cubano José Rojas Bez (2006, p. 101) ainda reforça que: "Las “imágenes' literarias no se generan directamente desde estímulos visuales, aunque sí se relacionan con una experiencia previa de los mismos."

A literatura colaborou e ainda colabora sobremaneira com a qualidade técnica e científica dos filmes desse gênero. Assim sendo, podemos dizer que até a década de 1950 o conceito de filmes soft predominava e a partir desse período o conceito de filmes hard tiveram seu espaço garantido, respaldados pelas literaturas mencionadas até aqui. Também é possível observar que a fama negativa que a FC tinha em relação aos demais gêneros do cinema veio diminuindo com o passar do tempo. 
Mas quem decide qual roteiro é melhor ou pior? Que filmes poderemos assistir e quais conteúdos farão parte dele? Os produtores.

Por tales razones, dichos medios suelen caracterizarse a partir del concepto de difusión, ya que los poseedores de los recursos para filma y exhibir los filmes (imprimir periódicos, transmitir rádio y televisión...) difunden ideas entre un público que, como norma, no 'contesta', como en un diálogo, sino ve o escucha una especie de 'monólogo' y es influido por él. (BEZ, 2006, p. 76).

Com o tempo, esses produtores perceberão a existencia de outras obras tão importantes quanto essas do início do século passado, que estão espalhadas pelo mundo da literatura, agora mais complexo em sua expanção e divulgação, visto a quantidade de publicações que não alcançamos por se tratarem de pequenas tiragens ou pequenas editoras. Com o desenvolvimento das tecnologias atuais para a leitura eletrônica, das redes de relacionamento na divulgação e uma expressiva diminuição da barreira da língua, será facilitado consideravelmente o acesso a essas novas ideias por parte dos roteiristas e produtores de cinema. Apesar de que como nos lembra Bez (2006), sempre atrelado a interesses econômicos, políticos e culturais.

Lembrando como afirma Guimarães (2003 p. 91-92):

O processo de adaptação, [...] não se esgota na transposição do texto literário para um outro veículo. Ele pode gerar uma cadeia quase infinita de referências a outros textos, constituindo um fenômeno cultural que envolve processos dinâmicos de transferência, tradução e interpretação de significados e valores histórico-culturais.

\section{Referências}

AGUIAR, F. Literatura, cinema e televisão. In: PELLEGRINI, T. et al. Literatura, cinema $e$ televisão. São Paulo: SENACl, 2003.

BEZ, J. R. El cine entre las artes: reflexiones estéticas sobre cine. Habana: Pueblo y Educación, 2006 .
COMPARATO, D. Da criação ao roteiro: o mais completo guia da arte e técnica de escrever. Rio de Janeiro: Rocco, 2000.

DUARTE, R. M. Cinema \& educação. Minas Gerais: Autêntica, 2002.

FOULCAULT, Michel. Vigiar e punir: nascimento da prisão. Petrópolis: Vozes, 1987.

GUIMARÃES, H. O romance do século XIX na televisão: observação sobre a adaptação de os maias. In: PELLEGRINI, T. et al. Literatura, cinema e televisão. São Paulo: SENAC, 2003.

KOFF, R. F. Pensando com o cinema. Santa Maria: Ed. UFSM, 2002.

VERNE, J. Da Terra à lua. São Paulo: Hemus, 1971a.

1971b.

Viagem ao redor da lua. São Paulo: Hemus,

XAVIER, I. Do texto ao filme: a trama, a cena e a construção do olhar no cinema. In: PELLEGRINI, T. et al. Literatura, cinema e televisão. São Paulo: SENAC, 2003. 